PF 2019 (LXXIII): 67-90

\author{
JULIA DOMITRAK \\ Wydział „Artes Liberales” \\ Uniwersytet Warszawski \\ ul. Nowy Świat 69, 00-046 Warszawa \\ e-mail: juleczka.dom@hotmail.com
}

\title{
NAZWY ISTOT MŁODYCH W GWARACH POLSKICH NA BRASŁAWSZCZYŹNIE - KONKURENCJA FORM RODZIMYCH I ZAPOŻYCZONYCH ${ }^{1}$
}

SŁOWA KLUCZOWE: polskie gwary kresowe, słowotwórstwo, nazwy istot młodych, afiks, interferencja, rejon brasławski

KEYWORDS: Polish borderland dialects, derivation, names of young creatures, affix, interference, Braslaw region

\section{NAMING YOUNG CREATURES IN POLISH DIALECTS \\ OF THE BRASLAW REGION - A TENSION BETWEEN THE NATIVE AND THE BORROWED FORMS}

\begin{abstract}
The rivalry between the Belarusian, Russian and Polish forms in Polish dialects of Braslaw region can be easily traced in the terms of lexical category denoting young creatures' names (baby animal names). On the one hand, we observe the use of the dominating young creatures' names formed by means of the (Lithuanian)Belarusian affix $-u k$, on the other hand, the North-Polish -ak and the Russian -onok (also in the adapted form -onek). This is due to the co-functioning of several languages that constantly interact and influence the Polish language. The comparison of the number of derivatives in the register and the number of usage in the texts collected in the electronic corpus shows that despite the expansion of foreign affixes in Polish dialects, native forms still maintain their position and are frequently used.
\end{abstract}

1 Referat został wygłoszony na Ogólnopolskiej Konferencji Naukowej „Małe języki Europy”, organizowanej przez Instytut Filologii Słowiańskiej UWr we Wrocławiu 23 maja 2016 r. Niniejszy tekst jest jego wersją zmienioną i rozszerzoną. 
Dzisiejsza Brasławszczyzna to graniczący z Litwą i Łotwą rejon brasławski, który znajduje się na północnym zachodzie Republiki Białorusi. Miasto rejonowe Brasław leży w obwodzie witebskim. Badany obszar w znacznym stopniu pokrywa się z przedwojennym powiatem brasławskim województwa wileńskiego, który obejmował też pograniczne wsie na Litwie. Współcześnie (2009 r.) rejon brasławski zamieszkuje 29175 osób, w tym 5444 Polaków (18,6\%), 18843 Białorusinów (64,6\%), 4160 Rosjan (14,2\%). Liczba Polaków mieszkających w mieście wynosi ok. 32\%, na wsi 68\% (Перепись 2009, s. 110) ${ }^{2}$.

Wielojęzyczna i wielokulturowa ludność ziem pogranicznych budzi zainteresowanie etnografów i językoznawców, stanowiąc ważny przedmiot badań naukowych. Brasławszczyzna jako obszar przenikania się kultur, religii i języków była obiektem wieloletnich badań Elżbiety Smułkowej wraz z zespołem (Iryna Budźko, Nijola Birgiel, Olga Guszczewa, Helena Kazancewa, Inessa Kuryan). Owocem ich pracy jest dwutomowa monografia Brasławszczyzna. Pamięć i współczesność (Smułkowa 2009, 2011). Monografia, która jest poświęcona w szczególności historii, sytuacji socjolingwistycznej i językom regionu brasławskiego, zawiera słownik „dwujęzycznych mieszkańców rejonu” oraz duży zbiór tekstów mówionych (polskich, białoruskich, dwujęzycznych i mieszanych, oraz staroobrzędowców). Inne podejście teoretyczne i metodologiczne do tej problematyki przedstawia Janusz Rieger w monografii Słownictwo polszczyzny gwarowej na Brasławszczyźnie (2014). Autor analizuje sytuację językową badanego obszaru, wskazując główne cechy polszczyzny gwarowej, zwraca uwagę na współfunkcjonowanie wyrazów zapożyczonych i rodzimych, pokazuje ponadto frekwencję wybranych par wyrazowych. Praca zawiera słownik ${ }^{3}$ liczący ok. 5000 wyrazów oraz „hasła rzeczowe”, które pokazują w tekstach ciągłych zmieniające się warunki historyczne, życie codzienne, społeczne i religijne mieszkańców badanego obszaru. Obszar ten przyciągał także uwagę językoznawców z Instytutu Językoznawstwa Narodowej Akademii Nauk Białorusi i wielu innych.

Sytuacja językowa polszczyzny na Brasławszczyźnie jest zróżnicowana. Pod względem językowym rejon brasławski można podzielić na dwie części: wschodnią i zachodnią. We wschodniej części, gdzie było mniej wsi polskich, mówiono gwarą białoruską, rzadziej posługiwano się językiem polskim. Obecnie językiem prymarnym tamtejszych Polaków jest gwara białoruska, rzadziej język rosyjski. Polszczyzna na ogół nie jest używana na co dzień, chociaż znają ją ludzie starsi. Kontakt z językiem polskim u osób starszych ogranicza się dzisiaj głównie

\footnotetext{
2 Перепись населения 2009. Национальный состав населения республики Беларусь, t. III. Минск 2011. Pozyskano z http://www.belstat.gov.by.

Oparty głównie na nagraniach i zapisach Anny Stelmaczonek-Bartnik, Barbary Jasinowicz (z lat 2000-2005), Wiktora i Elżbiety Minksztymów, Natalii Ananiewej, kartotekach Wiaczesława Werenicza.
} 
do czytania książeczek do nabożeństwa, śpiewania pieśni religijnych, słuchania kazań - język polski pełni tu funkcję sakralną. W zachodniej części obszaru sytuacja wygląda nieco inaczej. Było tam więcej wsi zamieszkałych przez przekazującą polszczyznę z pokolenia na pokolenie drobną szlachtę oraz więcej polskich wsi chłopskich, co sprzyjało używaniu polszczyzny w lokalnych kontaktach pomiędzy miejscowościami. Liczne wywózki w latach 1939-1941, wyjazdy do Polski, a także do Łotewskiej SRR po roku 1945, masowe przenoszenie się do miast w związku z podejmowaniem pracy - wszystko to doprowadziło do drastycznego zmniejszenia się na tych terenach liczby ludności polskiej.

Po 1945 roku ludność napływowa z różnych stron byłego ZSRR, a także młodzież we wzajemnych kontaktach posługuje się językiem rosyjskim lub gwarą białoruską. Natomiast ci, którzy urodzili się tu w czasach, gdy ziemie te należały do Polski (tj. w latach 1922-1939), do dziś na co dzień posługują się językiem polskim. Znają język rosyjski ze szkoły, jak również język słyszany w radiu bądź telewizji i posługują się nim w różnych sytuacjach oficjalnych. Pokolenie średnie (urodzone w latach 1940-1960) znacznie rzadziej używało języka polskiego. W zachodniej części rejonu do niedawna zachowały się liczne rodziny, a także nieliczne wsie, w których językiem prymarnym jest język polski w jego regionalnej odmianie (Rieger i in. 2002).

Język polski na Brasławszczyźnie jako fenomen na styku kilku państw ${ }^{4}$ jest zagrożony wymarciem z powodu wciąż zmniejszającej się liczby użytkowników. Jeśli porówna się dane ze spisu ludności z lat 1931 i 1999 w dzisiejszym powiecie brasławskim na Białorusi, to widoczne są istotne różnice w liczbach mieszkańców deklarujących język polski jako ojczysty - 65,6\% ludności (1931 r.) wobec 2,58\% ludności (1999 r.) $)^{5}$. Współcześnie sytuacja wygląda inaczej ${ }^{6}$, gdyż użytkownikami polszczyzny są przeważnie przedstawiciele najstarszego pokolenia. Młodzież i dzieci mieszkające w obu częściach rejonu najczęściej nie znają języka polskiego, niektóre uczęszczają na fakultatywne zajęcia i poznają tam współczesny język polski (język prasy i telewizji), nieraz uczą się też regionalnej odmiany języka. Niemniej jednak język polski w rejonie brasławskim przetrwał mimo trudnych

\footnotetext{
4 Większość dawnego powiatu brasławskiego znajduje się dziś w granicach Białorusi, mniejsza część należy do terytorium Litwy.

5 E. Smułkowa za P. Eberhardtem podaje, że według spisu ludności z 1931 r. język polski jako ojczysty deklarowało $65,6 \%$ mieszkańców powiatu, a narodowość polską - 62,2\%. Według spisu ludności z 1999 r. w dzisiejszym rejonie brasławskim na Białorusi język polski jako ojczysty deklarowało 2,58\% ludności wobec 25,47\% ludności deklarującej narodowość polską (Smułkowa 2009, s. 104).

6 Dane spisu ludności z 2009 r. odnoszą się do obwodów bez podawania danych dla poszczególnych rejonów. Dlatego cytowanie liczb odnoszących się do całego obwodu witebskiego mijałoby się z celem.
} 
warunków historycznych i społecznych, a polszczyzna jest jeszcze pielęgnowana i używana przez najstarsze pokolenie w niektórych miejscowościach.

Na przykładzie wybranej kategorii, a mianowicie nazw istot młodych, chciałabym przedstawić zasób formantów tworzących ten inwentarz (zarówno charakterystyczne dla badanego obszaru, jak i mniej liczne czy jednostkowe, powstałe pod wpływem języków obcych), a także pokazać różnorodność form współfunkcjonujących na badanym terenie oraz podać frekwencję poszczególnych typów słowotwórczych.

W języku ogólnopolskim kategoria nazw istot młodych jest mało liczna, ale charakteryzuje się produktywnością, wyrażaną formantem paradygmatycznym na - $\boldsymbol{e}$ (w lm. -ęta) i sufiksalnym na - ak (Grzegorczykowa, Puzynina 1998, s. 429). Formant $-\boldsymbol{e}$ jest starszy, ma on źródło w prasłowiańszczyznie, zaś charakterystyczny dla Mazowsza sufiks - $\boldsymbol{a} \boldsymbol{k}$ jest nowszy ${ }^{7}$. W polszczyźnie występuje także formant $\boldsymbol{- u} \boldsymbol{k}^{8} \mathrm{w}$ kilku nacechowanych regionalnością nazwach istot młodych używany z odcieniem lekceważenia: w nazwach osób, np. Cyganiuk, hetmańczuk, lokajczuk, lub w nazwach zwierząt, np. sarniuk, parsiuk, psiuk, a także w regionalnej nazwie grzyba maśluk (Grzegorczykowa, Puzynina 1979, s. 204).

W białoruskim języku literackim, jak i w większości gwar białoruskich, głównym wykładnikiem kategorii nazw istot młodych jest formant paradygmatyczny na -’a (-’o), nр. ягн'я / ягн'ё 'jagnię, nарас'я / napaclë 'prosię. Nazwy te są również

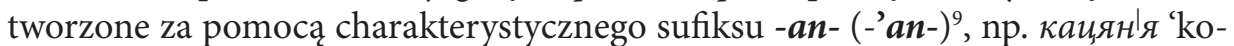
сіе̨, буслян'я 'pisklę bociana', por. brus. бусел (Аванесов 1964, s. 167; Бірыла, Шуба 1985, s. 259; Крывіцкі 2003, s. 169). W gwarach białoruskich w nazwach istot młodych także występuje formant $-\boldsymbol{u k}(-\boldsymbol{u} \boldsymbol{k})^{10}$, np. u̧in $y \kappa$ 'kurczę', ласюю 'łoszę' lub -onak (-’onak) ${ }^{11}$, np. дзіцё̈нак 'dziecko', ияляёнак 'cielę'. Szerzenie się typu słowotwórczego na -onak jest osobliwością gwar białoruskich północno-wschodniego areału dialektologicznego (Barszczewska, Jankowiak 2012, s. 123). Ten typ słowotwórczy jest produktywny i ma charakter regionalny, por. gwary witebskie, homelskie, mohylewskie, mińskie (Сцяцко 1977, s. 197-201). Leksykalny atlas gwar białoruskich podaje, że w rejonie brasławskim notowano formy

$7 \quad$ K. Czarnecka podaje za Dobrzyńskim (1974), że pierwsze derywaty z sufiksem -ak były notowane na początku XVII w. (Czarnecka 2009, s. 91).

8 Zapisany w rejestrze zapożyczonych formantów sufiksalnych (Długosz-Kurczabowa, Dubisz 2006, s. 368).

9 Natomiast tworzenie formacji określających nazwy istot młodych z sufiksem -onak tłumaczy się wpływem języka rosyjskiego.

10 Ten typ słowotwórczy jest produktywny w gwarach południowo-zachodnich i na Polesiu (gwary brzeskie, grodzieńskie).

11 Cechą charakterystyczną jest wymowa nieakcentowanego $o$ jak $a$ - tzw. akanie, typowe dla rosyjskiego i białoruskiego języka literackiego, dla znacznej części gwar białoruskich i rosyjskich, jak i dla gwar polskich na Brasławszczyźnie. 
z sufiksami -*ok, -*onok, np. казлёнак // казлянёнак, ваўчанёнак, кацёнак, гусёнак // гусянёнак, вуцёнак // вуиянёнак, we wschodniej części również -uk, por. казлюк // казял ок, ваўч|ук (ЛАБНГ тара 40, mapy 73-74, mapy 115-116).

W języku rosyjskim charakterystycznym i najbardziej produktywnym sufiksem tworzącym nazwy młodych zwierząt oraz istot niedorosłych jest -'onok (w liczbie mnogiej -ata), nр. волчонок, мьиш онок, орлёнок. Dla tworzenia nazw istot młodych wykorzystywano także inne sufiksy: -onysz, -ik /-czik, rzadziej -ок, nр. гусёныш, змеёныи, бегем'отик, крокодильчик, дельф|инчик, малёк, бел|ёк (Шведова 1980, s. 174, 201-202; Земская 2011, s. 38, 211).

W gwarach polskich na Ukrainie repertuar formantów tworzących nazwy istot młodych jest bardzo bogaty: dominują rzeczowniki na -ę oraz -ątko, także liczne formacje $\mathrm{z}-a k$ wraz $\mathrm{z}$ rozszerzonym wariantem -aczek oraz -uk i -uczek, pod wpływem ukraińskim pojawiają się formacje z -a / -’a i -atko / -etko, notowano też pojedyncze przykłady z -enia, -eniatko, -ynię, -yniętko, -yniątko, -aczę /-acza (Czarnecka 2009, s. 90-97).

$\mathrm{Na}$ Kresach północno-wschodnich charakterystyczne dla tej kategorii są sufiksy -ak (Turska 1983, s. 19; Dubicka 1986, s. 74) oraz -uk (tworzący również deminutiva). Sufiks -uk odnotowano w gwarach na Wileńszczyźnie (Turska 1983, s. 19; Dubicka 1986, s. 72; Dwilewicz 1997, s. 63-64; Dawlewicz 2000, s. 93; Rieger i in. 2006) oraz na Kowieńszczyźnie (Karaś 2002, s. 260-261; Rieger i in. 2006). W gwarach polskich na Litwie za pomocą sufiksu -uk tworzone są poszczególne grupy tematyczne, m.in. bardzo liczną grupę stanowią wyrazy będące nazwami zwierząt lub ptaków, w tym istot młodych, np. kabaniluk, wroniluk, zwierzuk (Rutkowska 2006, s. 99).

Opisując osobliwości słowotwórcze języka polskiego na Wileńszczyźnie XVI-XVIII w., Z. Kurzowa wskazuje m.in. na produktywność formacji deminutywnych na -ek, $-k a,-k o,-i k$, zwłaszcza ich szerokie zastosowanie w zdrobnieniach drugiego lub trzeciego stopnia $z$ formantami -eczk-, -eńk-, -uszk-, -uszeczk-, -eniatki. Przyrostek -uk, -czuk dość często występował w XIX wieku w tekstach pisarzy kresowych, był używany zwłaszcza w rzeczownikach zdrobniałych, u J. Chodźki dzieciuk, wieprzuk, u Karłowicza ${ }^{12}$ cieluk, cieluczek, kurczuk. W dzisiejszej polszczyźnie wileńskiej, jaką posługuje się ludność pochodzenia wiejskiego, pojawiły się nowe formanty, np. -atko, -eniatko, -utka, -ucha (Kurzowa 1993, s. 250-256).

Uwagę B. Dwilewicz, że w języku mieszkańców wsi Bujwidze na Wileńszczyźnie „formant $-u k$ nie jest jednym formantem służącym do urabiania nazw istot młodych” i że „wykorzystywane są w tym celu również sufiksy charakterystyczne

12 W Podręczniku czystej polszczyzny dla litwinów i petersburszczan Karłowicza zamieszczona została przestroga przed używaniem pewnych zdrobnień rzeczowników na - $u k$, -uczek oraz przymiotników na -eńki, które były uznawane za cechę prowincjonalną (Kurzowa 1993, s. 252). 
dla języka ogólnego, lecz nie cieszą się one taką popularnością jak formant -uk i są używane w sytuacjach oficjalnych”, można odnieść także do Brasławszczyzny (Dwilewicz 1997, s. 63).

Słownik mówionej polszczyzny północnokresowej (2017), zawierający ok. 13400 haseł, przedstawia mowę polską ludności wiejskiej oraz miejskiej z terenów dawnych Kresów północno-wschodnich, deklarujących się jako Polacy. Podstawą materiałową słownika są zapisy tekstów nagranych przez autorów w latach 1987-2008 na dawnych Kresach i na Łotwie. Wykorzystane zostały też materiały z artykułów i książek innych autorów w okresie od 1925 do 2013 r. Autorzy wyróżniają następujące odmiany terytorialne polszczyzny - na Litwie Wileńskiej, Litwie Kowieńskiej, Białorusi Zachodniej, Białorusi Wschodniej oraz na Łotwie (SMPP 2017, s. 5-6). Słownik uwzględnia formy nazw istot młodych także z obszaru Brasławszczyzny. Spośród wyrazów należących do badanej kategorii liczne są formacje na -uk, np. kukawiuk 'pisklę kukułki', lisiuk 'lisek' LW, łosiuk 'łosię LW, motyluk 'motylek' LW, nutruk 'młode nutrii' LW, pawuk 'młody paw' LW, plisiuk 'pisklę pliszki' LK, szczuruk 'młoda mysz' LW, trusiuk 'króliczek' LW, BZ. W słowniku nie zanotowano nazw istot młodych na -onek / -onak (formant występuje w kilku deminutywach lasonek 'lasek' LK, świronek / świronak zdr. od 'świron' lub 'mały spichrz' LW, BW).

Atlas gwar wschodniosłowiańskich Białostocczyzny (2012) przedstawia nazwy istot młodych na czterech mapach ${ }^{13}$. Na całym terytorium przeważa formant paradygmatyczny - a pod akcentem (dzicila, żarabila, ciella, szczenila, jahnila) lub rozszerzony -ania (-enia, -ynia) (kaczanila, sabaczenila, husienila, kutynila). Na północnym zachodzie i północy rozpowszechnione są akcentowane formanty -ak (dzicilak, kaczlak, szczenilak, ciellak) oraz -uk (kaczluk, kiziluk, cielluk, parasiuk, sobaczluk // szczeniluk, sporadycznie dzieciuk). Sufiksy te często występują wymiennie w tym samym punkcie (Czurak i in. 2012, s. 32-41).

Podstawą materiałową niniejszego szkicu są nagrania z początku XXI wieku, w większości zebrane w elektronicznym korpusie tekstów gwarowych. Wykorzystano ok. 70 godzin nagrań magnetofonowych Anny Stelmaczonek-Bartnik oraz Barbary Jasinowicz z lat 2000-2005, także nieliczne nagrania Krystyny Rutkowskiej z dzisiejszej Litwy. Analizuję materiał zebrany z obszaru współczesnego rejonu brasławskiego po stronie białoruskiej, w mniejszym stopniu uwzględniam materiał z historycznej Brasławszczyzny, tj. ze strefy przygranicznej, znajdującej się obecnie po litewskiej stronie granicy. Większość nagrań pochodzi z zachodniej części badanego obszaru, informatorami były głównie osoby z najstarszego pokolenia. Dużą pomoc stanowi wspomniany słownik brasławski J. Riegera,

13 Wśród omawianych w atlasie wyrazów znalazły się: dziecko (mapa 7), kaczę - gęsię - kocię (mapa 8), szczenię (mapa 9), źrebię - cielę - prosię - jagnię (mapa 10). 
bogatego materiału dostarcza zwłaszcza wykorzystany w monografii słowniczek rzeczowników zebranych we wsi Gajdy przez Natalię Ananiewą (prawie 3500 wyrazów; maszynopis z 1974 r.) oraz Słowniczek wyrazów gwarowych, używanych w okolicach Dryświat, Gajd i Widz Witolda i Elżbiety Minksztymów (ok. 1200 wyrazów; 2010).

W gwarach polskich na Brasławszczyźnie w nazwach istot młodych w grupie ok. 120 rzeczowników dominuje formant $-\boldsymbol{u} \boldsymbol{k}$ - 28\% wyrazów. Mniej liczne są derywaty z formantami -'onek / -'onok ${ }^{14}$ (18\%) i ogólnopolskim -ak (12\%), natomiast nieliczne lub wręcz jednostkowe są formacje na -ę / -ęt-, -ątko / -ątek, -czyk, -ik, -ek, -ok, -ysz, -unia, -ka (-eńka, -eczka, -utka).

\section{Formacje $\mathrm{z}-\boldsymbol{u} \boldsymbol{k}$}

-'uk (-uk)

baraniluk 'baranek': Jedna owieczka przyniosła dwóch baraniuków Ba, GajA $\triangle$ SPGL $^{15}$ baraniluk Niem, SMPP baraniluk LW, LK, BZ; bocianiluk 'mały (młody) bocian': Jak mówi jajka [bocian] wyrzuci, to na wojna, a jażeli bocianiuka, to na głod $\mathrm{Bi}$, GajA $\Delta$ SPGL bocianiluk Jez, SMPP bocianiluk/ bacianiluk/bucianiluk LW, LK; cielluk 'cielę': Trzymali cieluklou, nie mieli gdzie stawat' nie było tych postrojek Gaw, MM, GajA (brus. gw. иялююк) $\Delta$ Kurz cieluk, SPGL cielluk Jez, Niem, Wiln, cialuk Kow, SMPP cielluk LW, BZ, cialluk LK; dzieciluk 'dziecko, dzieciak': Rodziła dzieciuka i pazwali jej pakazać Bi, Dzieciuki, nie wyrabiajcie się! MM (brus. gw. дзяиюк) $\Delta$ SPGL dzieciuk Kow, Niem, Wiln, SMPP dzieciluk/dzieciluk/dziaciluk LW, LK, BZ; gołębiluk 'pisklę gołębia’ GajA $\Delta$ SMPP gołębiluk/gułębiluk LW; jagniluk 'jagnię’ MM (brus. gw. ягнюю) $\triangle$ SPGL jagniluk 'jagnię, baranek' Niem, Wiln, SMPP jagniluk/ jagniluch/jegniluk LW, BZ (Wi); jaskólluk 'pisklę jaskółki' GajA $\Delta$ SPGL

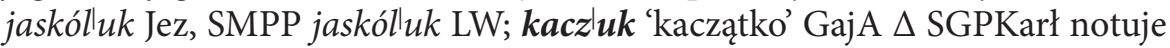
kaczuczek z Litwy, SMPP kaczluk LW, BZ (Wi); kociluk 'kotek' MM $\Delta$ SMPP klociuk/kaciluk LW; koźlluk 'koźlę, koziołek': Onla przywykła, leci, szuka jak swoj koźluk już jejny Ba, GajA $\Delta$ SMPP koźluk LW; kurczluk 'kurczę’: Jeżeli chce tam kurczukow, to już matka tedy da tam kopiejka Ba, Jes tam i kurczuki wszy ${ }^{i}$ skie je Gal, A tute j źdźobajo kurczuki kWi, GajA (brus. gw. кypulyк) $\Delta$ Kurz kurczuk, SPGL kurczluk Ejsz, Jez, Kow, Wiln, SMPP kłurczuk/kurczluk

\footnotetext{
14 Zapożyczony -onok (po miękkiej spółgłosce) i -onek w postaci zaadaptowanej traktuję jako warianty, podaję więc liczbę procentową dla obu formantów łącznie.

15 Formacje $\mathrm{z}-u k$ są częste w polszczyźnie gwarowej na Litwie i notowane w miejscowościach różnych obszarów: obszar niemenczyńsko-mejszagolski (Niem), obszar ejszysko-solecznicki (Ejsz), obszar jezioroski (Jez), obszar ignalińsko-smołwieński (Ign), na Kowieńszczyźnie (Kow) i w okolicach Wilna (Wiln).
} 
LW, LK; lalluk 'niemowlę' MM (brus. gw. лlяля); parsiluk ${ }^{16}$ 'wieprzek': Podkopywal i tam tego parsiuka karmil kOp, Tam jednego parsiukla zakolim u rok, ten cały rok i jedzo tego parsiukla kWi, Rano wyjdziem, rosa zimna, paść trzeba krowy, a tego, a krowa dzie parsiuka Gr, Parsiukaż kłujo [na wesele] Ba, MM, GajA (brus. gw. napcюк, napulyк, lit. Paršiùkas) $\Delta$ Kurz parsiuk/parszuk 'młody wieprz, prosiak', SGPKarł parsiuk/parszuk, prosiuk z Litwy, SPGL parsiuk Ejsz, Ign, Jez, parszuk Kow, SMPP parsiluk/parszluk LW, LK; prkaluk 'cielę' GajA ( $p r^{u} k a-p r^{u} k a$ 'przyzywanie cieląt'); psiuk 'szczenię' GajA $\Delta$ SWil psiuk posp. 'młody, mały pies', SMPP psiuk LW, LK, BW, Ł; ptaszluk $\boldsymbol{k}^{17}$ 'pisklę' GajA (brus. gw. nmawlyk) $\Delta$ SMPP ptaszluk LW, LK; sowiluk 'pisklę sowy' GajA; sroczluk 'pisklę sroki' GajA; świniluk 'prosię' GajA $\Delta$ SMPP świniluk LK; wilczluk 'szczenię wilka' GajA (brus. gw. ваўulyk); żrebluk 'źrebak, źrebię' MM, też żereb|uk GajA (brus. gw. жарабу $к$ ) $\triangle$ SPGL żrebuk Wiln, żerebuk Jez, Kow, Niem, Wiln, SMPP źrebuk/żrebuk/żrabluk/żrybluk/żarabluk 'młody koń przed osiągnięciem wieku 3 lat, źrebak' LW, Ł

też: czarciluk 'diabełek (o nieznośnym dziecku)' MM; diabluk: Dzieciuka rodziła i mawiła: czysty diabluk Bi $\Delta$ SPGL diabluk Jez, SMPP diabluk LW

$-u l u k(-u k !)$

czyżulluk 'pisklę czyżyka' GajA (z niejasnym -ul-)

Być może formant -uluk powstał z kontaminacji -ula $+-u k$, por. występujące w materiale wyrazy w zn. 'dziadek' dziadula kOp, dziaduk kRy, Gaw, Gr, lub według analogii do formantu -ulek, np. zębulek 'ząbek' kRy, kOp, GajA, gdzie -ulokreśla zdrobnienie/spieszczenie. W Mowie ludu polskiego K. Nitsch przytacza występującą na południu Śląska nazwę czyžulczę i wskazuje na wyrazy określające rodziców - ojciec Czyž, matka Czyžula (Nitsch 1911, s. 66). Biorąc pod uwagę istnienie ewentualnej podstawy czyżula, nienotowanej w materiale, można stwierdzić, że derywat czyżuluk wpisuje się w podstawowy model słowotwórczy $\mathrm{z}$ formantem $-u k$. W gwarach notowane są inne formacje $\mathrm{z}-u l a$, jak mamula, babula, dziadula.

Istnieją różne interpretacje genezy formantu -uk. Najczęściej podkreśla się jego litewsko-ruskie pochodzenie. W. Martynow, próbując odnowić system słowotwórczy dla stanu prasłowiańskiego i bałtosłowiańskiego, wyprowadza pochodzenie formantu od bałtyckiego -ukas (jego odpowiedniki to w języku lit. -ùkas, łot. -ucis). Przemawia za tym nie tylko fonetyka, ale również geografia lingwistyczna, w szczególności zachodniorosyjsko-białorusko-ukraińsko-polski areał, który graniczy z bałtyckim. Zdaniem autora, słowiańskie deminutivum umownie

16 W wyrazie parsiuk - zapożyczonym z litewskiego - synchronicznie wyraźne jest zakończenie $-u k$, które może być kojarzone $\mathrm{z}$ sufiksem - $u k$ mimo braku podstawy derywacyjnej.

17 SGPKarł odnotowuje ptasiuki 'ptaki' (Wisła. Miesięcznik geograficzno-etnograficzny). 
rekonstruowane jako ${ }^{\star}-u k$ (por. brus. вяпрук, ukr. малюк, pol. szczeniuk) nie jest rdzennie słowiańskim formantem (Мартынов 1973, s. 31).

Na Kresach północnych formant - uk jest przejawem interferencji języka litewskiego ${ }^{18}$ lub też rezultatem kontaktów z białoruszczyzną. Jak wskazuje J. Rieger, cechy litewskie mogły przedostać się najpierw do gwar białoruskich, by potem poprzez medium białoruskie trafić do polszczyzny, która wyrosła na substracie białoruskim. Na terenach takich jak Brasławszczyzna może się to wiązać z powstaniem nowego sąsiedztwa białoruskiego wskutek równoczesnej czy następującej w niewielkich odstępach czasu białorutenizacji sąsiednich wsi litewskich i wpływu języka ich mieszkańców na mowę Polaków (Rieger 2006, s. 22).

Z. Kurzowa, opisując formacje słowotwórcze charakterystyczne dla języka polskiego i „dialektu” północnokresowego XVI-XVIII w., odnotowuje formację z -uk, której podstawą jest wyrażenie przyimkowe podwieprzuk 'młody wieprz', i podkreśla ruskie pochodzenie sufiksu (Kurzowa 1993, s. 122).

W polszczyźnie jezioroskiej i ignalińskiej H. Karaś notuje 30 formacji z sufiksem rzeczownikowym -uk (104 wystąpienia: 61 na obszarze jezioroskim, 43 ignalińskim). Charakteryzuje się on wielofunkcyjnością i występuje m.in. w nazwach istot młodych (np. chłapczuk, zwierzuk), deminutywach męskich (np. papuk'tatuś, trajbulusiuk 'zdr. trolejbus'), a także w imionach i nazwiskach. Przy czym cztery formacje odznaczają się większą częstotliwością, por. cieluk // cialuk, dzieciuk // dziaciuk, dziaduk // dzieduk, papuk (w rejonie jezioroskim), pozostałe wyrazy poświadczono rzadziej lub sporadycznie (Karaś 2017, s. 230-234).

Formant $\boldsymbol{- u} \boldsymbol{k}$ jest bardzo produktywny i tworzy stosunkowo liczne formacje (20 wyrazów); oprócz tego w dwu formacjach czarciluk, diabluk sufiks - $u \boldsymbol{k}$ wyraża ekspresywność, np. czysty diabluk [o dziecku], podobny o toż, toż. I rożeczki czutku czutku znaczni i kopyteczki Bi.

Wpływem białoruszczyzny należy tłumaczyć odmienne od ogólnopolskiego miejsce akcentu. W niemal wszystkich wyrazach (z wyjątkiem dwóch) mamy akcentowany w mian. l.poj. sufiks -uk.

Oprócz wyżej omówionych derywatów formant - $u k$ występuje w rozszerzonej postaci jako -uczek $(-u k+e k)$, tworząc rzeczowniki deminutywne (lub o zabarwieniu hipokorystycznym):

-uczek

baraniuczek GajA; cieluczek: Syslun ot bliszczy przy krowie chtóry bywszy cieluczek $\mathrm{Ba}$, Cieluczek, jaka cieli sie, stlabieńki zupetni Gr, Nu teraz u mnie... dwa cieluczkli, dwie owieczki, dwoje świń Gaw $\Delta$ Kurz cieluczek, SPGL

$18 \mathrm{~W}$ języku litewskim sufiks -ùkas jest produktywny w nazwach istot młodych (paršiukas 'prosię, veršiùkas 'cielę,' kačiukas 'kociątko'), tworzy deminutiva (kambariukas 'pokoik' $\leftarrow$ kambarys 'pokój') oraz hipocoristica (broliùkas 'braciszek' $\leftarrow$ brólis 'brat'). 
cieluczek Niem, Kow, SMPP cieluczek/cialuczek LW, BZ; dzieciuczek MM $\Delta$ SMPP dzieciuczek/dziaciuczek LK, BZ, Ł; gajdziuczek 'młody kogut' MM (lit. gaidùkas 'kogucik') $\triangle$ SMPP gajdziuk LW; gęsiuczek 'pisklę gęsi, gąsiątko' GajA $\Delta$ SMPP gęsiuczek/gęsiuczak LW, BZ (Ig); kociuczek GajA $\Delta$ SMPP kociuczek/kaciuczek/kaciuczak/kuciuczek LW; koźluczek GajA; parsiuczek 'prosię': Musim i parsiuczka jakiegoś trzimać, i kura jakaś trzymać kGir, Tam parsiuczka jakiego kłuli Gaw, Tylko krowa, dwa parsiuczki malileniaczkie kRy, My wozili parsiuczków do Widz Ba, Parsiuczka wyhadujesz, gdzie schowasz, o tak kOp, Parsiuczek na mięsa On, Też menczyła sie, jedna też i parsiuczka czszymała kWi, MM, GajA (brus. gw. napсючloк) $\Delta$ SPGL parsiuczek Ejsz, Ign, Kow, Niem, Wiln, SMPP parsiuczek LW, parciuczek BZ; psiuczek 'szczeniak' GajA $\Delta$ SMPP psiuczek 'piesek' LW, LK, psiuczak BZ; żerebuczek 'źrebak, źrebię' GajA (brus. gw. жарабуиloк) $\Delta$ SPGL żerebuczek Wiln

Pojawiają się też nazwy innych zwierząt, nieużywanych w znaczeniu deminutywnym, np. burluk 'baran' GajA, też basiluk i bosiluk GajA, ciecierluk 'cietrzew' MM (por. brus. цеияр $y \kappa)$, gęsiluk 'gąsior' GajA, indiluk 'indyk' GajA (ros. инд|юк), też indycz'uk GajA, pacluk 'szczur' Nu, MM, GajA, ziutiluk 'gęs' GajA, zwierzluk 'zwierz, zwierzęta' GajA (brus. звер, ros. зверь $\Delta$ SWil zwierz).

Można zaobserwować, że formacje $\mathrm{z}-u k$, -uczek są charakterystyczne dla zachodniej części Brasławszczyzny i często używane w miejscowościach położonych blisko granicy z Litwą.

Formacje z -'onek, -'onok

-'onek

baranionek GajA; jaskólonek 'pisklę jaskółki' GajA; cielonek: a tak pare świni dlia siebie cielonek ten to nie tam ku'nia mamy Gaw, My to dużo trzymali w zeszłym roku sześć, a w tym roku dwie krowy i trzy cielonki, to mało bardzo $\mathrm{Nu}, \mathrm{Gaj} A$ (brus. gw. иял|ёнак, ros. телёнок); dziecionek 'dziecko': Pszyszła mama ten dziecionek no co rodziwszy sie zmarznienty, płaczy, asz sini $\mathrm{Za}$, A ono wiesz, tak paść dziecionku cienżko $\mathrm{Nu}$, Zawionż ten pempek, dziecionek ten, zawionzywała Drś, Babka przyjmi dziecionka kWi, Bi, Wj, GajA (brus. gw. дзяц्ёнак, ros.-star. детlёнок); korszunionek 'pisklę jastrzębia' GajA (por. brus. карш|ун, ros. אориун) $\Delta$ SGPKarł karszun z Litwy, korszun z okolic Augustowa; pisklonek GajA; porosionek 'prosię': No tak wszyskoż trzymali parasionka tam kOp (ros. поросёнок); psionek 'szczeniak' GajA (ros. pot. псёнок, ros.-star. щенё̈нок); świnionek 'prosię' GajA (ros. pot. свинё̈нк); wilczonek 'szczenię wilka' GajA (brus. gw. ваўчан|я, ваўчанёнак, ros. волч|онок, ros.-star. волчен|ёнок); żerebionek 'źrebak, źrebię’ GajA (brus. gw. жарабёнак, ros. жеребёнак) 
-enionek ${ }^{19}$

sroczenionek 'pisklę sroki' GajA (por. brus. сарачан'я, ros. сороч|нок) -'onok (-'onak)

baranionok: Aj, pozdychali wielkie, teraz wielki baranionak, z tyłu jej chodzit $\mathrm{Nu}$; cielonok: Może jakiego cielionka wyhoduje sprzeda $\mathrm{kWi}, \mathrm{Nu}$; dziecionok: A teraz mówił dziecionok rodzi sie, my jich trzymami na ukołach $\mathrm{kWi}$, Dzie żeby uczycielki który dziecionok no to z roboty źwalniali Za, U jej córka była maleńka, dziacionak ostausia kOp, Już on biedny dziecionak paść, jemu od ile pudów żyta $\mathrm{Nu}, \mathrm{kMi}, \mathrm{Ba}, \mathrm{ArDa}$; koźlonok GajA (brus. gw. казлlёнак, ros. козл|ёнок, ros.-star. козленёнок); роrosionok kOp (brus. gw. парасёнак, ros. поросёнок); sowionok GajA (brus. савянё̈, ros. сов|ёнок)

-oneczek (-onoczek)

cieloneczek GajA; dziecioneczek: To moja siostra o ta o była kuma jeszcze, kścili tego dziecioneczka ArDa, GajA (ros.-star. детенёночек); porosionoczek: Parasiloneczka jednego trzymami w jesieńi drugiego beń[dzim] kupowa Gaw, Tam co jakiego parasilonoczka wyhadujesz, ta w katchloz oddali kWi

Większość derywatów tworzona jest za pomocą sufiksu w zaadaptowanej postaci. Sufiks jest rosyjski i wschodniobiałoruski. W zakresie kontaktów rosyjskich nie można wykluczyć nowszego wpływu szkoły, a także dawnego wpływu gwar staroobrzędowców rosyjskich.

W słowniku języka bilingwalnych mieszkańców rejonu brasławskiego pod red. E. Smułkowej zanotowano formacje na -’onek/-’onok/-’onak używane w różnych miejscowościach, czego potwierdzeniem są formacje występujące w badanym materiale: cielonek - w 14 wsiach, prosionek - w 12 wsiach, żerebionek - w 10 wsiach, dziecionek - w 15 wsiach, świnionek - w 3 wsiach, koźlonek - w 2 wsiach, baranionek - w 1 wsi i in., jak i niewystępujące w nim jagnionak, jelenionak, hałubionak, husionek, kacionak, kaczenionak // wucionak, kralonak // trusionak, kukuszonak, kurczonak // ciplonak, lisionak, łosionak, miedzwieżonak, myszonak, skowronek // żawronak, szczenionak // sabaczonak, wronionek. Jest prawdopodobne, że do gwar białoruskich formacje te docierały najpierw od starowierców, a potem z języka rosyjskiego (np. w kołchozach), co potwierdza mapka pokazująca „układ terytorialny znajomości języków i gwar” na Brasławszczyźnie w latach 1997-2007²0

19 W gwarach staroobrzędowców rosyjskich typem słowotwórczym charakterystycznym dla nazw istot niedorosłych jest ten z rozszerzonym sufiksem -епіonok, nр. зайч-енёнок, кот-енёнок, собач-енёнок (Семенова 1963).

20 Na mapie oznaczono miejscowości, w których obserwowano występowanie lokalnej polszczyzny, gwary białoruskiej, dyglosji polsko-białorusko-rosyjskiej, bilingwizmu białorusko-polskiego, oraz miejscowości, w których obserwowano tylko znajomość języka polskiego albo jego rzadkie użycie. 
(Smułkowa 2009, s. 107). O. Guszczewa podkreśla, że gwara staroobrzędowców, pojawiających się na terenie Brasławszczyzny w drugiej połowie XVIII wieku, nie miała znaczącego wpływu na miejscową polszczyznę i białoruszczyznę, ponieważ była to grupa etniczna izolowana od innych. Zauważa jednak, że niektóre wypowiedzi świadczą o utrzymywaniu kontaktów sąsiedzkich i o rzadkich małżeństwach mieszanych (Smułkowa 2009, s. 214).

Ogólnosłowiański atlas językowy (2000) w rejonie brasławskim ${ }^{21}$ notuje wyrazy z formantem -onılk, -onak: kac'anonak // kac'anonılk, ščan’onıık, žarab’onak, c'al'onıı, jahnonıı, kazl'onıık, paras'onıı, c'iplonıık// kurčonıık, gus'onıık//gusonak, wuc'onıık// wuc'onak (ОЛА mapy 25-34).

\section{Formacje z-ak, -aczek}

Zanotowano 8 formacji z sufiksem - $a k$, który historycznie jest mazowiecki, stąd na Brasławszczyźnie bardziej naturalny, i 6 formacji z rozszerzonym wariantem -aczek. $-a k$

bydlak GajA; ciellak: Mieli dwie krowy i cielaków hodowali Ju, Małych cielaków, poić trzeba było, karmić, przyuczać Cz, Ja dużo pracowała, cała życia na fermie dojarka cielaków Gaw, St, Bi, kRy, GajA $\Delta$ SMPP cielak/ciellak LW, BZ; czajlak 'pisklę czajki' GajA; dzieciak: Zimno, czszeba tego dzieciaka umyć Drś, kGaj, Cz $\Delta$ SMPP dziecilak BZ, LW, Ł; kurczlak 'kurczę' GajA $\Delta$ SMPP kurczak 'pisklę kury' LW; prosiak: Tam można było i drugo już trzymać i cieliaka jakiego i prosiaka Drj, Teraz my nie trzymamy prosiaków kOp, Prosiaka jednego zakolo ArDa, A u nas to takaj nigdy nie była, żeby zdemować skóra $z$ tego prosiaka kGir, Nu, Ma, Cz, Ja, PelDrś $\triangle$ SMPP prosiak LW; szczeniak GajA $\Delta$ SPGL szczeniak 'młode' Niem

tu też formacja z prefiksem pod-: podcielak 'mały roczny cielak (!)': Ali i ogierów było u kogo na stajni, świni, nu podcielaki, tam kury to wszystko SzDo

-aczek

cielaczek GajA $\Delta$ SMPP cielaczek LK; dzieciaczek: Byt o taki zdrowy dzieciaczek, i jakoś, nie wiem co sie stało ale tak szypko zmar Cz $\Delta$ SMPP dzieciaczek BZ, L, Ł; kaczaczek GajA; kurczaczek GajA; parsiaczek: Teraz mam jednu krowku i dwóch parsiaczkow St; prosiaczek: Pamientam, ze zabijali prosiaczka kGir, Był prosiacze $e^{y}$ osmiomisięczny, zakrojilismy jego Op, I krowa czszyma, ona jaszcze prosiaczka, kurków Stn, Nu gospodarke, mam tylko krowke, prosiaczka mam, wszysko co, sam ja Ma, Tak, krówka sie trzymie, dwóch prosiaczków, jeszcze kWi $\Delta$ SMPP prosiaczek BZ

${ }^{21}$ Miejscowość Lukszy jest położona $15 \mathrm{~km}$ na północ od Brasławia. Informatorzy: WB (1917 ur., 6 klas polskiej szkoły), FA (1913 ur., 4 klasy polskiej szkoły), LB (1925 ur., 4 klasy polskiej szkoły). 
Formant - $\boldsymbol{a} \boldsymbol{k}$ został odnotowany w niedużej liczbie wyrazów. Sufiks ten ma charakter regionalny i w gwarach Polski etnicznej występuje głównie na terenach Mazowsza i północnej Polski (Grzegorczykowa 1984, s. 57; Cyran 1977, s. 16; Zdancewicz 1966, s. 76-78), na pograniczu zarówno wschodnim, jak i polskowschodniosłowiańskim (Kowalska 1979). Jak stwierdza K. Nitsch, rzeczowniki typu cielak, źrebak, kurczak są znane w całej Polsce, ale tylko na północy Polski typ ten występuje wyłącznie (Nitsch 1911, s. 66). W. Taszycki zaznacza, że w pojawieniu się pierwszych form na -ak odegrał rolę czynnik semantyczny w postaci dążności do wydzielania się pod względem rodzajowym zespołu męskiego i tworzenie opozycji oznaczającej bardzo małe stworzenia oraz stworzenia podrosłe typu cielę : cielak (Turska 1984, s. 47).

W języku ogólnym formacje $\mathrm{z}$-ak mogą być nacechowane ekspresywnie (np. dzieciak, bydlak). W analizowanym materiale jest to forma neutralna, o czym świadczą przytoczone przykłady z wyrazem dzieciak: Dawniej, jak [nauczyciel] zobaczy u dzieciaka tego krzyżyk na tego, na szyji powieszony, to gotowa głowa oderwać Drś; To jeszcze mój tatuś był dzieciak... On dzieciak został mały od rodziców kGaj; Staruszka, rence o czszenso sie, źle zawionża, z krwi zejdzie dzieciak... Zimno, czszeba tego dzieciaka umyć Drś; Już tam i dzieciaki jest, już nioso tam jim jeść $\mathrm{Bi}$.

Niektóre formacje z sufiksem -ak są akcentowane na pierwszej od końca sylabie na wzór derywatów z akcentowanym -uk. Przeważnie są to wyrazy ze słowniczka wsi Gajdy autorstwa Ananiewej, por. bydlak, cielak, czajak, kurczlak.

Na uwagę zasługuje formacja podcielak, którą można interpretować dwojako: derywacja została utworzona za pomocą przedrostka pod-i podstawy słowotwórczej cielak na wzór brus. gw. падсвінак, ros. подсв инок 'prosiak w wieku od 4 do 10 miesięcy'22 albo mamy do czynienia z transpozycją odpowiedniego wyrazu brus. gw. падиё̈лак (пяр эзімак) 'roczne zwierzę, roczniak'.

$$
\text { Formacje na }-\boldsymbol{e} / \text { - } \boldsymbol{e} t \text { - }
$$

$\mathrm{W}$ materiale poświadczono także wyrazy $\mathrm{z}$ formantem dziś paradygmatycznym na -ę / -ęt- (są to nazwy niepodzielne). W wypowiedziach występują częściej $\mathrm{w}$ formie liczby mnogiej:

jagnię GajA; cielę (lmn. cielęta): Wtedy poszłam pracować koło cielont, pracowałam $\mathrm{Cz}$, Trzeba na śpiski jedno krowe mieć, ludzie chowajo te cielenta dzieś kGir, Nie tylko świniom można i cielentam i krowam można PelDrs, Kałchozy przyjmujo, tych cielont zdam, wszysko miesionc pokarmie a późni zdam Ma, To ja już przy cielentach byŭ i jak raz na pensje paszled Gaw, Nu nie

22 SMPP notuje podświnek z Białorusi Wschodniej za: Dombroski, Cz. (1932). Ze słownictwa i gramatyki języka ludności polskiej na Białorusi sowieckiej. Mińsk. 
małych cielentaw ale takich dzie plemianych Gim, Ik, Cc $\Delta$ SMPP cielę/cielont LW, Ł; kurczę (lmn. kurczęta): Ona dla kurczont jajclo zgotowała SzDo; prosię (lmn. prosięta): Nu był koń, dwie krowy, nu tam owieczki kury, nu prosiaki prosiata [poprawia się] prosienta tam, nu, wszysko takie co u gospodarce Ma; ptaszę (lmn. ptaszęta): ptaszęta śpiewaja Op

$$
\text { Formacje z-atko,-atek }
$$

\section{-ątko (-ątek ?)}

Cyganiątko: i uxu ji z Cyganiontkam unona była Za; dzieciątko: A jeści temu dzieciontku to po ksionżkach, a karmi kWi, Święta Teresa od Dzieciątka Jezus, od tego czasu bardzo dużo zaczęli chrzcić Tereska Cz, Ojcze nasz mówim, tam jakie do Dzieciontka Jezus jakie dzie co umiemy Gim, Okna wybiła $i$ z tym dzieciontkiem wyleźli przez okno Ko, I uot ja u ten czas rodziła drugiego, i rodziła tego dzieciontka prosto, u watówce nadziauszy sie, abuuszy sie Za;

pisklatko: My jusz, w liatach jestem, no to po co nam to, ta bydła, nu trzymamy jakiegoś piskliantka jednego no Gaw

-atek

jagniątek r.m. GajA; pisklątek r.m. GajA (N. Ananiewa wskazuje na rodzaj męski wyrazów)

Formant -ątko uważa się za połączenie syngulatywno-deminutywnego sufiksu - ko z cząstką - ąt- wyabstrahowaną z paradygmatu formacji na -ę. Oprócz informacji o młodym wieku sygnalizuje małość i ekspresywność (Kreja 1969, s. 99-100; Grzegorczykowa, Puzynina 1998, s. 429). Stwierdzony przez N. Anianiewą rodzaj męski może mieć związek z brakiem rodzaju nijakiego w języku litewskim $^{23}$ (a Gajdy to teren litewski) lub/i pod wpływem formacji na -onok/ -onek (w Gajdach częste są formy na -onek, por. wyżej jaskólonek, pisklonek).

\section{Inne formacje}

Kilka z przedstawionych niżej formacji znajduje się na pograniczu dwóch wyróżnionych grup nazw istot młodych oraz nazw deminutywnych. Tworzone są one za pomocą następujących formantów:

\section{Formacje z - ek}

-ek

baranek: Przychodzo unony z roboty $i$ tłumaczo dzieciom że mama, i tatu $\dot{z} e$, mocno mówi baranyk Za; baranczyczek GajA ( $\leftarrow$ baranczyk); byczek: Tam,

23 Por. O. Vaičiulytė-Romančuk (2009, s. 16-17). 
un mnie byk, byczek u pani tam ciele Ma, A jest tam bydło, krowa wo, byczek tam, prosiak Gaw, GajA $\Delta$ SMPP byczek/byczak LW; chłopczyczek 'malutki chłopiec': I chłopczyczek ten spawity wszystko, leży pamyty DwGr $(\leftarrow$ chłopczyk); gołąbek/gołębek GajA, też gołąbeczek/gołębeczek GajA; indyczek GajA (brus. gw. індзючок); kociczek GajA (« kocik); kotek GajA, też koteczek GajA; korszunek ( $\leftarrow$ korszlun 'jastrząb', brus. gw. карulyн, ros. коршlyн); ptaszek 'pisklę’ GajA ( $\leftarrow$ ptach, ptaszluk, z ucięciem), też ptaszeczek GajA $(\leftarrow$ ptaszek)

$$
\text { Formacje } \mathrm{z}-\boldsymbol{i} \boldsymbol{k}
$$

$-i k$

bracik 'młodszy brat': A tu o bracik moj onż młodszy ode mnie na czszy latki tak ten co umar Stn, Ja mówie, że no bracik już jest chory kMi (brus. $\sigma_{p}$ laui $i \kappa$,

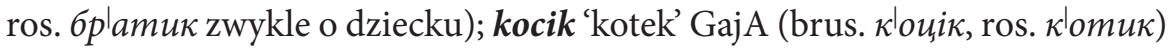
$\triangle$ SMPP kocik Ł; kogucik ogp. kogucik: Krowka jest, pieńć kurak, kogucik kDrś

$$
\text { Formacje z-czyk }
$$

$-c z y k$

baranczyk GajA, WiW; kabańczyk 'warchlak' MM ( $\leftarrow$ kaban, por. brus. кабанчык, ros. кабанчик) $\Delta$ SWil kaban prow. na Litwie i Rusi 'młody wieprz, wieprzak', SGPKarł kaban 'młody wieprz', SMPP kabanczyk 'prosiaczek' LW

tu też można zaliczyć chłopczyk: Chłopczyk chodził, może do szóstej klasy ci co, taki maliusieńki ArDa, Tenczas poszła na robota z tym chłopczykiem mniejszym Stn, Ja znalazła na słomie chłopczyka, przyniosła wam DwGr ( $\leftarrow$ chłopiec, z ucięciem) $\Delta$ SMPP LW

$$
\text { Formacje } \mathrm{z}-\boldsymbol{k} \boldsymbol{a}
$$

$-k a$

ciućka 'piesek' MM ( $\leftarrow$ ciucia) $\Delta$ SJPD ciucia, ciućka 'szczenię, mały piesek; małe prosię', SGPKarł ciućka 'pieszczotliwa nazwa psa, szczególnie szczeniąt' z Litwy, SMPP ciućka pieszcz. 'szczenię, piesek' LW; dzietka ${ }^{24}$ 'dziecko (przy zwracaniu się także do osob młodszych, również nieznajomych)’: Idź dzietka, pozlow tam babcia Drś, Dojiła po dwadzieścia

24 Wyrazy dzietka, dziletoczka, dzileteńka często są używane przy zwracaniu się do osób młodszych czy nieznajomych, np. O taka życia mnie dzietka przeszła Stn, Teraz ze wszyskim inaczej, dziletoczka moja miła kWi, Nikogo nie nie ma już u nlas, aj dziletoczka Gaw, Jak akulary adziene to paczytam i książeczka jaż dawniejsza co, dzietańka moja droga kWi. 
krów, czszy razy w dzień, o tak, moja dzietka kWi, kRy, Gim, Bi, GajA

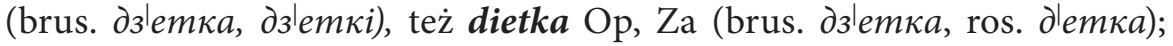
dziewczynka: Tyko słyszym zakrzyczała o mówi dziewczynka narodziła sia DwGr, A drugiej córki jedna dziewczynka to tamta chodziła do rosyjskiej, żłóbek kGaj, i była u ich dziewczynka już mała ArDa, dwie dziewczynki piersze byli umarli Stn, kRy, kWi (por. też brus. дзяўч|ъıна); krówkal krowka: Ja krowka ponakarmie, napoje krówki kOp, Mam tylko krowke, prosiaczka mam Ma, też korowka: Nu to karowka u mamy zastałaś kGir (brus. gw. кар оўкa); kukutka 'prosię' GajA ( $\leftarrow$ kukuta, kukucia 'świnia'; por. lit. kükùtis $\Delta$ SMPP kukutka 'świneczka' LW, kukucia 'świnka, prosię' LW; mallyszka 'mała dziewczynka': A to okrzczony, to jeszcze małlyszkami byli, A tam a ta małyszka poszła u sadzik, a potym małyszka do szkoły poszła kWi ( $\longleftarrow$ małlysz 'maluch', brus./ros. мaлlııшкa); owieczka 'młoda owca': No, krówke, ciołke jleszcze, owieczka jest kOp, Stn, kWi, Dw, Ma $\triangle$ SMPP owieczka/awieczka LW, BZ; ziutka 'gąska' GajA ( $\leftarrow$ ziuta-ziuta 'przywoływanie gęsi'), tu też lmn. dzietki 'dzieci': Doczekali by dzietków Ko, Myśle sobie dzietki nie lękajcie sie wy mnie kWi, Mialutkie poumierali dzietki... tak było po siedem po dziesieńć dzieci Stn, Bi $\Delta$ SGPKar dziatki Łęczyckie, okolice Żarek, Siewierza

-eczka

ciołeczka GajA ( $\leftarrow$ ciołka 'jałówka’ z ucięciem, por. brus. gw. цёлка, цёлачка, ros. пёлка); ciełuszeczka/ciałuszeczka: choć malenka dadzo ciałuszeczka $\mathrm{Ba}, \mathrm{U}$ pani tam ciele, ciełuszeczka - wymieniamy sie Ma, ArDa, GajA ( $\leftarrow$ ciełuszka, brus. gw. ияллушка $\Delta$ SWil ciełuszka prow. ob. cielica, Kurz ciełuszka, SPGL ciełucha, ciełuszka, ciełuszeczka Wiln, SGPKarł ciełuszka, ciełuszeczka 'cieliczka' z Litwy); gąseczka GajA; koteczka: Kot był a ze mno taka koteczka Nu; kroweczka GajA; owieczeczka: A tutej sianka pasłana i te jest te owieczeczki, jest pasterzy tam ArDa -eńka

dzi|eteńka: Zabacz ty, dzietańka, czego dziś dziedluk tak długo śpi kRy, GajA (por. SGPKarł dziateńka z Lubelskiego)

$-u t k a$

krowutka GajA; basiutka 'młoda owca' GajA ( $\longleftarrow$ baś baś, też bazia bazia 'okrzyk przywoływania owiec', por. lit. basiùkas, basiùlis 'jagnię' $\Delta$ SMPP baziutka/baziut'ka 'owieczka' LW; barutka 'młoda owca' GajA (por. lit barute, barutis w in. zn.)

$-u l k a$

tu lmn. dzietulki 'dzieci’ MM 
Formacje z-unia

-unia

krowunia GajA

Formacje $\mathrm{z}-\boldsymbol{o} \boldsymbol{k}$

$-o k^{25}$

byczok Gaw; synok: Jak poszła on był i poszed $z$ domu, Kazik... synok, przyszłam zobaczyć coś mój dzicionak, nu i poszed Ko (brus./ros. сын'ок) $\Delta$ SMPP synlok BZ (Wi)

Formacje z-ary

$-\operatorname{ary}^{26}$

dzieciary 'dzieci': Tak samo ja widziała jak wywozili [na Syberię], siedzo dzieciary ma[łe], nogi paabkrencany wieźli Drś

Formacje $\mathrm{z}-\boldsymbol{y s} \boldsymbol{z}$

Do grupy nazw istot młodych można zaliczyć też zapożyczony z rosyjskiego wyraz matysz 'maluch': I mnie małyszla ciagnie razem $\mathrm{kWi}$, I rodziła tego małyszla, dziecionka tego Za, dwóch małyszlej mamy Gaw, GajA ( $\leftarrow$ mały, brus./ros. мал skiego matlyszka kWi. Morfem -ysz występuje więc w dwóch wyrazach.

Wśród omawianych wyżej wyrazów mogą występować synonimy, a to wskutek tworzenia nazw młodych zwierząt tak od nazwy ojca/matki, jak i od innych podstaw, por. młode świni jest określane przez informatorów jako prosię $\mathrm{Ma}$, prosiak kOp, kGir, Cz, PelDrś, ArDa, Nu, Ja, Gaw, Drj, Stn, prosiaczek Op, kWi, Ma, Stn, świniluk GajA, parsiluk kOp, kWi, Gr, Ba, MM, GajA, parsiuczek kGir, Gaw, kRy, Ba, kOp, On, kWi, MM, GajA, porosionek kOp, parasilonoczek kWi, świnionek GajA, kabańczyk MM, kukutka GajA; młode krowy - cieluk Gaw, MM, GajA, cieluczek Ba, Gr, Gaw, cielonek Gaw, Nu, GajA, cieloneczek GajA, byczek Ma, Gaw, GajA, prkaluk GajA; młode psa - psiuk GajA, psiuczek GajA, szczeniak GajA, psionek GajA, ciućka MM. W wyżej wymienionych przykładach widoczne są także dublety słowotwórcze ${ }^{27}$.

25 SMPP notuje porasiok 'wieprzek, prosiak' LK.

26 Kontekst wskazuje na opowiadanie ze współczuciem, co wyklucza zgrubienie.

27 Określeniem dublety słowotwórcze posługuję się za M. Sajewiczem: „są to nazwy posiadające to samo znaczenie słowotwórcze, oparte na tych samych podstawach słowotwórczych, lecz utworzone za pomocą różnych formantów" (Sajewicz 1989, s. 267). 
W zakresie nazw istot młodych najbardziej charakterystyczne dla polszczyzny rejonu brasławskiego są następujące zjawiska:

- przewaga nazw istot młodych z (lit.)-brus. - $\boldsymbol{u} \boldsymbol{k}$ (co jest charakterystyczne dla polszczyzny północnokresowej), z drugiej strony - z północnopolskim sufiksem - $\boldsymbol{a k}^{28}$,

- używanie spolszczonego formantu -onek (z ros. -ёнок (-онок), też brus. gw. -ёнак (-онак)) tworzącego dużą liczbę formacji,

- występowanie dubletów słowotwórczych, np. jaskólluk - jaskólonek, ptaszluk - ptaszek, pisklątek - pisklonek, sroczluk - sroczenionek, świnionek - świniluk, wilczluk - wilczonek, psiuk - psionek, dzieciluk-dzieciak-dzie-

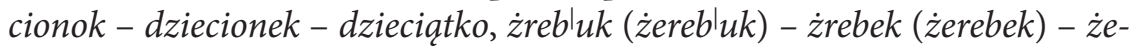
rebionek; często w parze dubletów znajdują się wyrazy z tożsamymi, lecz genetycznie obcymi rdzeniami. Niekiedy jeden informator używa obocznie dwóch form, np. Dzieciuka rodziła... nu czysto normalny dziecionak BiKG19, Nu tam owieczki kury, nu prosiaki [poprawia się] prosienta tam, nu, wszysko takie co u gospodarce... prosiaczka mam wszysko co, sam ja, widzi pani MaMB37

Frekwencja w ramach szeregów synonimicznych opracowana na podstawie sporządzonego przeze mnie elektronicznego korpusu tekstów pokazuje „moc” poszczególnych formantów:

- dziecko (86 użyć) - dzieciątko (6 użyć) - dzieciak (14 użyć) // dzieciaczek (1 użycie) - dziecionek/dziecionok (29 użyć) // dziecioneczek (2 użycie) - dzieciluk (3 użycia). Przy czym przy derywacie dziecionek dochodzi element emocjonalny, np. A on tylko ze szkoły, z seminarium, a Boże mój Boże, siedzi nu dziecionek taki siedzi kDrś, Szkoda mnie tego dziecionka $\mathrm{kWi}$.

- cielę/cielęta (14 użyć) - cielak (10 użyć) - cielonek (3 użycia) - cielluk (3 użycia) // cieluczek (3 użycie)

- prosię/prosięta (2 użycia) - prosiak (17 użyć) // prosiaczek (5 użyć) // parsiaczek (2 użycia) - porosionek (3 użycia) // porosionoczek (1 użycie) - parsiluk (8 użyć) // parsiuczek (18 użyć)

$\mathrm{O}$ „mocy” formantów świadczy również liczba derywatów utworzonych za pomocą danego sufiksu: -uk i -uczek (34 formacje), -ak i -aczek (14 formacji), -'onek wraz z wariantami (21 formacji).

28 Sufiks - ak jest rozpowszechniony w gwarach całego Mazowsza i Podlasia, a także na obszarze Warmii i Mazur (AGP 2). 


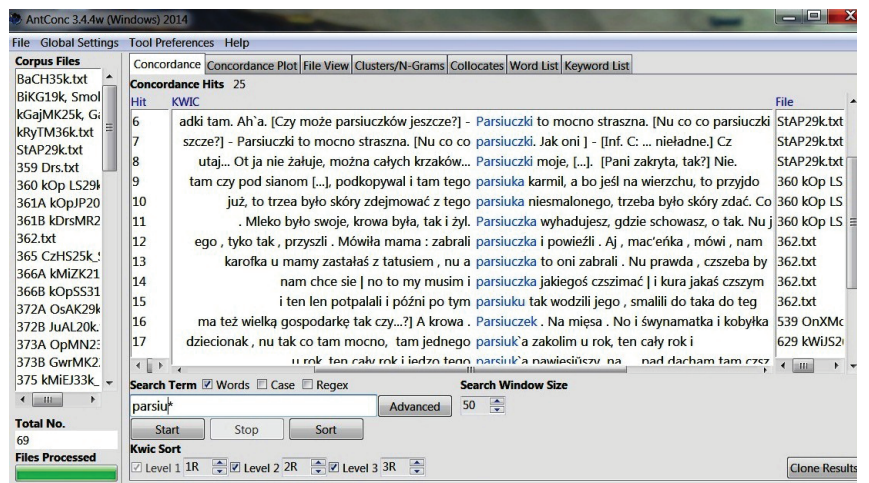

Rys. 1. Wyszukiwanie formacji parsiuk i parsiuczek w elektronicznym korpusie tekstów ${ }^{29}$

Tabela formantów przedstawia liczbę derywatów w rejestrze oraz liczbę użyć $\mathrm{w}$ tekstach na podstawie korpusu elektronicznego ${ }^{30}$. W tabeli pominięto formanty rzadkie i jednostkowe, jak: -ik (3 wyrazy, 3 użycia), -czyk ( 3 wyrazy, 3 użycia), -ok (2 wyrazy, 2 użycia), -ysz (1 wyraz, 7 użyć), -ary (1 wyraz, 1 użycie), -unia (1 wyraz).

\section{Tabela formantów}

\begin{tabular}{|c|c|c|}
\hline Formant i warianty & $\begin{array}{c}\text { Liczba derywatów } \\
\text { w rejestrze }\end{array}$ & $\begin{array}{l}\text { Liczba użyć } \\
\text { w tekstach }\end{array}$ \\
\hline \multirow{3}{*}{$\begin{array}{c}-u k \\
-u c z e k\end{array}$} & 24 & 22 \\
\hline & 10 & 21 \\
\hline & 34 & 43 \\
\hline \multirow{3}{*}{$\begin{array}{c}-a k \\
-a c z e k\end{array}$} & 8 & 42 \\
\hline & 6 & 8 \\
\hline & 14 & 50 \\
\hline \multirow{3}{*}{$\begin{array}{c}\text {-onek / -onok (-onak) } \\
\text {-enionek / -oneczek } \\
\text { (-onoczek) }\end{array}$} & 17 & 37 \\
\hline & 4 & 3 \\
\hline & 21 & 40 \\
\hline \multirow{3}{*}{$\begin{array}{c}-e-(-e ̨ t-) \\
-a t k o \text { / - atek }\end{array}$} & 5 & 18 \\
\hline & 5 & 8 \\
\hline & 10 & 26 \\
\hline \multirow{4}{*}{$\begin{array}{c}-k a \\
\text {-eczka /-eńka /-utka /-ulka } \\
\text { *-ka w odniesieniu do } \\
\text { osób dorosłych (dzietka) }\end{array}$} & 8 & $\approx 80^{1}$ \\
\hline & 11 & 6 \\
\hline & $* 3$ & $* 52$ \\
\hline & 19 & $\approx 86$ \\
\hline$-e k$ & 13 & 9 \\
\hline
\end{tabular}

Źródło: opracowanie własne

29 Przy czym w podanej frekwencji uwzględniam wystąpienie danego wyrazu tylko u informatora, a nie użycie tego wyrazu przez eksploratora.

$30 \mathrm{~W}$ swoim opracowaniu posługuję się programem korpusowym AntConc 3.4.4w autorstwa L. Antony'ego (Faculty of Science and Engineering Waseda University in Japan), dostęp: http:// www.antlab.sci.waseda.ac.jp/software.html 
$\mathrm{W}$ rejestrze dominują derywaty $\mathrm{z}$ formantem $-u k$, ale $\mathrm{w}$ korpusie przeważają derywaty $\mathrm{z}$ formantem -ak. Mocne pozycje, jeśli chodzi o liczbę derywatów i częstotliwości użycia, utrzymuje formant -onok/-onek. Można zatem wnioskować, że mimo szerzenia się obcych formantów w gwarach polskich rodzime formy wciaż utrzymują swoją pozycję i są często używane.

Analiza zjawisk słowotwórczych pozwala również ukazać konkurencję form rodzimych i wschodniosłowiańskich w gwarach polskich, co stanowi uzupełnienie dotychczasowych badań w zakresie fonetyki i leksyki. Pokazanie konkurencyjności formantów rodzimych i obcych w innych kategoriach słowotwórczych będzie częścią mojej rozprawy doktorskiej.

\section{Skróty nazw miejscowości i regionów}

Ar - Arcimowicze (koło Opsy), ArDa - Arcimowicze-Dalekie, Ba - Barteliszki (koło Smołw), Bi - Bieluniszki (koło Smołw), Cc - Czernica (koło Bohinia), $\mathrm{Cz}$ - Czerniowo (koło Drujska), Da - Dalekie (na pd. wsch. od Opsy), Drś - Dryświaty, kDrś - koło Dryświat, Dw - Dworzyszcze (na pd. wsch. od Dryświat), DwGr - Dworzyszcze-Grytuny, Gaj - Gajdy (na pn. wsch. od Rymszan), kGaj - koło Gajd, Gal - Galiniszki (na pd. od Dryświat), Gaw - Gawrany (na pd. od Dryświat), Gim - Gimzy (na pd. od Dryświat), Gir - Girejsze (na pn. zach. od Dryświat), kGir - koło Girejsz, Gr - Grytuny, Ig - Ignaciszki, Ik - Ikaźń (na wsch. od Brasławia), Ju - Jursze (na zach. od Widz), Ko - Kobyliszki (koło Dryświat), Ma - Mamiany (koło Dryświat), Mi - Milki, kMi - koło Milek, Nu - Nurwiany (koło Dryświat), On - Onikiszki (Wojnikiszki na pn. od Widz), Op - Opsa, kOp - koło Opsy, Pel - Pelikany (koło Opsy), PelDrś - Pelikany-Dryświaty, Ry - Rymszany, kRy - Mejkszty (dziś Litwa), St - Stryłungi (na zach. od Widz), Stn - Stankowicze (na pn. od Dryświat), SzDo - Szałteny-Domasze, Wi - Widze, kWi - koło Widz, Wj - Wojckieluny (na pd. od Dryświat), Za - Zamosz-Dryświaty; Ejsz - obszar ejszysko-solecznicki, Ign - obszar ignalińsko-smołwieński, Jez - obszar jezioroski, Kow - Kowieńszczyzna, Niem - obszar niemenczyńsko-mejszagolski, Wiln - okolice Wilna; LW - Litwa Wileńska, LK - Litwa Kowieńska, BZ - Białoruś Zachodnia, BW - Białoruś Wschodnia, Ł - Łotwa.

\section{Skróty}

GajA - Ананьева, Н. (1974). Альтернации в парадигматике существительных польского говора деревни Гайде Игналинского района ЛССР (maszynopis pracy). Москва; 
MM - Minksztym, W., Minksztym, E. (2010). Słowniczek wyrazów gwarowych, używanych w okolicach Dryświat, Gajd $i$ Widz. W: J. Rieger, D.A. Kowalska (red.), Język polski dawnych Kresów Wschodnich, t. IV (225-263). Warszawa: Semper;

Kurz - Kurzowa, Z. (1993). Język polski Wileńszczyzny i kresów pótnocno-wschodnich $X V I-X X$ w. Warszawa-Kraków: Wydawnictwo Naukowe PWN;

SPGL - Rieger, J., Masojć, I., Rutkowska, K. (2006). Słownictwo polszczyzny gwarowej na Litwie. Warszawa: DiG;

SGPKarł - Karłowicz, J. (1900-1911). Słownik gwar polskich, t. I-VI. Kraków: Akademia Umiejętności;

SMPP - Grek-Pabisowa, I., Ostrówka, M., Jankowiak, M. (2017). Słownik mówionej polszczyzny północnokresowej. Warszawa: Instytut Slawistyki PAN;

SWil - Zdanowicz, A., i in. (1861). Słownik języka polskiego. Wilno (tzw. Słownik wileński);

ЛАБНГ - Бірыла, М.В., Мацкевіч, Ю.Ф. (рэд.). (1993). Лексічны атлас беларускіх народных гаворак: у 5 т, t. І. Раслінны і жывёльны свет. Мінск 1993: Навука і тэхніка;

ОЛА - Общеславянский тингвистический атлас. Серия лексикально-словообразовательная. Животноводство. (2000). Выпуск 2. Варшава;

brus. - Суднік, М.Р., Крыўко, М.Н. (2002). Тлумачальны слоўнік беларускай літаратурнай мовы. 3-е выд. Мінск: Беларуская Энцыклапедыя ім. Пётруся Броўкі. Колас Я., Крапива К., Глебка П. (ред.). (1953). Русско-белорусский словарь. Москва: Госиздат иностр. и нац. словарей. Pozyskano z http://www.skarnik.by/

brus. gw. - Слоўнік беларускіх гаворак паўночна-заходняй Беларусі і яе пагранічча: у 5 т. (1979-1986). Мінск;

lit. - Lyberis, A. (2001). Lietuvių-rusų kalbų žodynas. Vilnius: Mokslo ir enciklopediju leidybos institutas. Larinas, B. (1967). Rusų-lietuvių kalbų žodynas. Vilnius: Leidykla „Mintis”. Lietuviu kalbos žodynas: elektroninis variantas (1-20, 1941-2002). Redaktorių kolegija: G. Naktinienè (vyr. red.), J. Paulauskas, R. Petrokienė, V. Vitkauskas, J. Zabarskaitè. Programuotojai: E. Ožeraitis, V. Zinkevičius. Vilnius: Lietuvių kalbos institutas, 2017. Pozyskano z http://www.lkz.lt/

ros. - Ушаков, Д.Н. (ред.) (1934-1940). Толковый словарь русского языка. Москва. Ожегов, С.И., Шведова, Н.Ю. (2006). Толковый словарь русского языка. Москва;

ros.-star. - Семенова, М.Ф. (ред.). (1963). Материаль для словаря русских старожильческих говоров Прибалтики. Рига: Латвийский государственный университет им. Петра Стучки. 


\section{Bibliografia}

Barszczewska, N., Jankowiak, M. (2012). Dialektologia białoruska. Warszawa: Slawistyczny Ośrodek Wydawniczy PAN.

Cyran, W. (1977). Tendencje słowotwórcze w gwarach polskich. Łódz: Zakład Narodowy im. Ossolińskich.

Czarnecka, K. (2009). Słowotwórstwo gwar polskich na Ukrainie. Rzeczownik. Czasownik (maszynopis rozprawy doktorskiej). Warszawa: Wydział Polonistyki Uniwersytetu Warszawskiego.

Czurak, M., Golachowska, E., Maryniakowa, I., Pastusiak, K., Rembiszewska, D. (2012). Atlas gwar wschodniosłowiańskich Białostocczyzny, t. IV. Słowotwórstwo. Instytut Slawistyki PAN. Warszawa: Slawistyczny Ośrodek Wydawniczy.

Dawlewicz, M. (2000). Słownictwo socjolektu młodzieży polskiego pochodzenia $w$ Wilnie (na podstawie badań ankietowych). Warszawa: Dom Wydawniczy Elipsa.

Długosz-Kurczabowa, K., Dubisz, S. (2006). Gramatyka historyczna języka polskiego. Warszawa: Wydawnicwta Uniwersytetu Warszawskiego.

Dobrzyński, W. (1974). Z badań nad rozwojem polskich deminutywów, t. I, Historyczny rozwój rzeczowników z formantem -ę na tle słowiańskim. Wrocław: Państwowe Wydawnictwo Naukowe.

Dubicka, B. (1986). Niektóre odrębności słowotwórcze polszczyzny wileńskiej. W: J. Rieger, W. Werenicz (red.), Studia nad polszczyzna kresowa, t. IV (71-79). Wrocław-Warszawa-Kraków-Gdańsk-Łódź: Zakład Narodowy im. Ossolińskich.

Dwilewicz, B. (1997). Język mieszkańców wsi Bujwidze na Wileńszczyźnie. Warszawa: DiG.

Grzegorczykowa, R., Puzynina, J. (1998). Problemy ogólne słowotwórstwa oraz Rzeczownik. W: R. Grzegorczykowa, R. Laskowski, H. Wróbel (red.), Gramatyka współczesnego języka polskiego. Morfologia, t. II (361-468). Warszawa: Wydawnictwo Naukowe PWN.

Grzegorczykowa, R., Puzynina, J. (1979). Słowotwórstwo współczesnego języka polskiego. Rzeczowniki sufiksalne rodzime. Warszawa: Państwowe Wydawnictwo Naukowe.

Karaś, H. (2002). Gwary polskie na Kowieńszczyźnie. Warszwa-Puńsk: Aušra.

Karaś, H. (2017). Język polski pogranicza litewsko-łotewsko-białoruskiego w świetle frekwencji cech językowych. Warszawa: Wydział Polonistyki Uniwersytetu Warszawskiego.

Kreja, B. (1969). Słowotwórstwo rzeczowników ekspresywnych w języku polskim. Formacje $n a-i k$, -k-, -isko i -ina. Gdańsk: Gdańskie Towarzystwo Naukowe.

Kowalska, A. (1979). Zróżnicowanie słowotwórcze gwar Mazowsza i Podlasia. Rzeczownik, t. II. Atlas. cz. 1. Mapy 101-200, cz. 2. Wykaz i komentarze do map 101-200. Wrocław-Warszawa-Kraków-Gdańsk: Zakład Narodowy im. Ossolińskich.

Kurzowa, Z. (1993). Język polski Wileńszczyzny i kresów północno-wschodnich XVI-XX w. Warszawa-Kraków: Wydawnictwo Naukowe PWN. 
Nitsch, K. (1911). Mowa ludu polskiego. Kraków. Pozyskano z http://zbc.uz.zgora.pl/dlibra/doccontent?id=17492

Rieger, J. (2006). Polszczyzna gwarowa na Litwie. W: J. Rieger, I. Masojć, K. Rutkowska, Słownictwo polszczyzny gwarowej na Litwie (11-47). Warszawa: DiG.

Rieger, J. (2010). Słowotwórstwo gwarowej polszczyzny kresowej. Problemy metodologiczne. W: J. Rieger (red.), Studia nad polszczyzna kresowa, t. XII (65-78). Warszawa: Semper.

Rieger, J. (2014). Słownictwo polszczyzny gwarowej na Brasławszczyźnie. Warszawa: Sub Lupa.

Rieger, J., Stelmaczonek, A., Jasinowicz, B. (2002). O języku polskim w rejonie brasławskim na Białorusi. Sytuacja językowa. W: J. Rieger (red.), Język mniejszości w otoczeniu obcym (35-55). Warszawa: Semper.

Rutkowska, K. (2006). Lituanizmy w gwarach polskich na Litwie. W: J. Rieger, I. Masojć, K. Rutkowska, Słownictwo polszczyzny gwarowej na Litwie (73-108). Warszawa: DiG.

Smułkowa, E. (red.). (2009, 2011). Brasławszczyzna. Pamięć i współczesność, t. I, II. Warszawa: Wydawnictwa Uniwersytetu Warszawskiego.

Turska, H. (1983). Język polski na Wileńszczyźnie. W: J. Rieger (red.), Studia nad polszczyzna kresowa, t. II (15-23). Wrocław: Zakład Narodowy im. Ossolińskich.

Turska, H. (1984). W sprawie rzeczowników typu cielak. W: T. Friedelówna (red.), [Halina Turska], Wybór pism (1945-1962) (39-50). Toruń: Wydawnictwo Naukowe Uniwersytetu Mikołaja Kopernika.

Vaičiulytė-Romančuk, O. (2009). Wykłady z gramatyki opisowej języka litewskiego. Morfologia. Warszawa: Wydział Polonistyki Uniwersytetu Warszawskiego.

Zdancewicz, T. (1966). Wpływy białoruskie w polskich gwarach pod Sejnami. Poznań: Poznańskie Towarzystwo Przyjaciół Nauk.

Аванесов, Р.І. (рэд.) (1964). Нарысы па беларускай дыялекталогіi. Мінск: Русская диалектология.

Бірыла, М.В., Шуба, П.П. (рэд.) (1985). Беларуская граматыка, Ч. 1. Фаналогія. Арфаєпія. Марфалогія. Словаўтварэнне. Мінск: Навука і тэхніка.

Земская, Е.А. (2011). Современный русский язык. Словообразование. Москва: Флинта, Наука.

Крывіцкі, А.А. (2003). Дыялекталогія беларускай мовы. Мінск: Вышэйшая школа.

Мартынов, В.В. (1973). Праславянская и балто-славянская суфбиксальная деривация имен (Доклады VII Международного съезда славистов). Минск: Наука и техника.

Перепись населения 2009. Национальный состав населения республики Беларусь, T. 3. Минск 2011. Pozyskano z http://www.belstat.gov.by

Сцяцко, П.У. (1977). Беларускае народнае словаўтварэнне. Афіксальныя назоўнікі. Мінск: Навука і тэхніка.

Шведова, Н.Ю. (1980). Русская Грамматика, Т. 1. Фонетика. Фонология. Ударение. Интонация. Словообразование. Морфология. Москва: Наука. 


\section{Streszczenie}

Dzisiejsza Brasławszczyzna to graniczący z Litwą i Łotwą rejon brasławski, który znajduje się na północnym zachodzie Republiki Białorusi. Współcześnie rejon ten zamieszkuje 29175 osób, w tym 5444 Polaków (18,6\%), 18843 Białorusinów (64,6\%), 4160 Rosjan (14,2\%). Liczba Polaków mieszkających w mieście wynosi ok. 32\%, na wsi 68\%. Na przykładzie wybranej kategorii, a mianowicie nazw istot młodych, przedstawiono zasób formantów tworzących wspomniane nazwy (zarówno charakterystyczne dla badanego obszaru, jak i mniej liczne czy jednostkowe, powstałe pod wpływem języków obcych), a także pokazano różnorodność form współfunkcjonujących na badanym terenie oraz podano frekwencję poszczególnych typów słowotwórczych. 